\title{
3 \\ Political and economic challenges of petroleum dependency in Timor-Leste
}

\section{Guteriano Neves}

One cannot discuss Timor-Leste's development over the last 10 years without mentioning oil as part of the equation. Oil is part of the collective Timorese memory of occupation's dark history; it shapes the path of national development and will continue to shape the country's future with the hopes, dreams and even fantasies that it provides. It shapes the state's structure, policies and democratic institutions, elites' attitudes and behaviour, resource distribution, and the interactions between the state and its citizens. Numerous scholars focusing on Timor-Leste have been highlighting the issues associated with oil dependency since 2002. Although many politicians are aware of these problems, and many policies are in place to mitigate the negative effects of oil dependency, the temptation posed by easy money has proved to be far greater than the willingness to avoid its perils. Warnings about the problems of oil wealth include arguments that Timor-Leste is already subject to the 'resource curse', a term used to refer to 'the negative impacts of non-renewable resource wealth' on people in many poorer countries which rely on external revenue, primarily from petroleum (Scheiner 2015b: 73; see also the Introduction to this volume). The curse of oil is said to manifest itself in unsustainable spending, import dependency and the policies for national development promoted by the 
government (Neves 2011; Scheiner 2015a). This is a consequence of easy access to petroleum rent in order to meet short-term desires, rather than strategic long-term development (Scheiner 2015a).

One aspect of the 'resource curse' is the 'rentier state', a term coined by Hossein Mahdavy (1970: 428) to characterise Middle Eastern countries that have received a significant amount of revenue from external sources. In the Timorese context, the state has become a rentier state because the government is the primary recipient of petroleum revenues (Beblawi 1987: 385). The rentier state theory situates the state as the unit of analysis by explaining how petroleum dependency shapes the state's relations with society and its role in economic development. Furthermore, it describes the political institutions that are generated and sustained by rent, and examines the social and economic structures of it.

This chapter discusses one element of this literature on oil dependency by assessing the extent to which petroleum dependency has shaped the new state of Timor-Leste into a rentier state and affected its political economy dynamics. This chapter combines academic literature on rentier states with my first-hand experience working with a non-governmental organisation (NGO) and the Office of the President in Timor-Leste. It examines the impact of Timor-Leste's oil dependency over the last 10 years (2007-2017), a period in which the state rapidly expanded, by focusing on three areas affected by oil rent: political institutions, bureaucracy and economic structures.

\section{Rentier development?}

Although petroleum revenues have enabled the state to expand over the last 10 years, these revenues function as rent for the domestic economy because the petroleum industry is independent from the domestic economy; domestic inputs are not required in the production process. When the state's revenues are mainly derived from petroleum, the state becomes a rentier state. Hazem Beblawi (1987: 384-85) has identified three characteristics of the rentier state: rent dominates the economy; rent is externally derived; and only a few are engaged in the rent generation, whereas rent distribution impacts the majority. When the government is the principal recipient and distributor of the rent, the state becomes what Giacomo Luciani has termed an 'allocation state' (Luciani 1987: 69). 
These realities have been observed in Venezuela (Karl 1997) and Middle Eastern states (Kamrava 2005: 259; Mahdavy 1970: 432; Owen 2004). Writing on Venezuela's case, Terry Lynn Karl (1997: 64) observes that petro-states are 'institutionally too weak to resist further petrolization' and are 'permeated by interests vested in maintaining an oil-based model of accumulation'. Based on Venezuela's experiences, Fernando Coronil (1997: 2) quotes Venezuelan writer José Ignacio Cabrujas, who stated, 'Oil is fantastic and induces fantasies'. According to Coronil (1997), oil money has endowed the Venezuelan state with the 'magical power to remake the nation'; '[i] ts power to awaken fantasies enables state leaders to fashion political life into a dazzling spectacle of national progress through "tricks of prestidigitation"' (ibid.: 2). It does so by expanding bureaucracy, initiating state-led industrialisation, providing social security schemes and expanding social services. Although state-led development gained popularity during the 1950s, in Middle Eastern countries oil indeed facilitates state expansion (Owen 2004: 23) without facing the balance of payment problems (Mahdavy 1970: 432; Owen 2004: 25).

Since the early period of independence, oil has been part of national imaginations of Timor's future. Oil provides easy money that enables politicians to dream up fantastic plans for the country's future; it is a source of hope for modernity and a better life. These imageries of modernity have informed economic policies in Timor-Leste since 2002. The 2011-2030 strategic development plan, which envisions TimorLeste to be a 'middle-income country' by 2030 , places oil at the centre of this vision. According to the introduction (GoTL 2011: 9), having 'one of the world's most vital commodities, petroleum' can help TimorLeste to secure the foundation of a sustainable and vibrant economy. Petroleum revenue will be 'invested in education and health services ... in helping farmers to increase their productivity', funding infrastructure, diversifying the economy and transforming the 'country into a modern nation' (ibid.). This has enabled the state to expand in various sectors over the last 10 years (Neves 2016). The availability of petroleum revenues eventually shapes the state's revenues and expenditure pattern. In 2015 alone, 89 per cent of the state's budget was transferred from the Petroleum Fund (MoF 2015: 6). Between 2011 and 2015, Timor-Leste would have suffered budget deficits of more than US $\$ 1$ billion every year if not for oil money (MoF 2015: 6). Between 2008 and 2012, the annual budget vastly increased, making Timor-Leste one of the world's leading countries in terms of budget growth (La'o Hamutuk 2011: 7). 
The state's expansion can be observed in the state's bureaucracy, statefinanced infrastructure projects, the existing insecure social security regime and social services, which have expanded rapidly in number and cost since 2008 (Neves 2013). As the country has only a nascent private sector, the role that business plays in economic development is nonexistent. Thus, it is a pragmatic decision for the public sector to be the engine driving economic development. Xanana Gusmão, politician and former guerrilla leader, set in motion the government's infrastructurefocused program, which includes roads, public buildings and electricity (see also Almeida, Chapter 5; Bovensiepen, Chapter 6; and Meitzner Yoder, Chapter 4). Government allocations for infrastructure account for 30 to 40 per cent of the total budget. They reached nearly 50 per cent of the total budget and non-oil gross domestic product (GDP) in 2011 and, in 2016, infrastructure-related spending alone accounted for more than 43 per cent of the total state budget. According to the World Bank, this is 'one of the highest rates of infrastructure spending in the world' (World Bank and Ministry of Finance 2015: ix). The government has also established cash transfer schemes for groups, such as veterans (participants in Timor-Leste's 24-year resistance to Indonesian occupation), the elderly and single-parent households (see also Roll, Chapter 7). According to the World Bank (2013: 1), Timor-Leste's social spending is 'one of the highest budget outlay ratios in the world', higher than all other countries 'with similar population size, poverty headcount, level of mineral resource wealth and fragile state status'. The biggest portion of social security spending goes to veterans, accounting for 60 per cent of the total Ministry of Social Solidarity social assistance budget (ibid.: 3).

Overall, according to the Asian Development Bank (ADB 2015: 1), although revenue from the Joint Petroleum Development Area is modest by international standards, on average, it contributed 80 per cent to Timor's GDP from 2006 to 2012. In 2014, oil accounted for 66.4 per cent of Timor's GDP, with the non-oil sector at 33.6 per cent (NSD 2015: x). Even for the non-oil economy, to a large extent, petrodollar is recycled through the state budget. Charles Scheiner, from the NGO La'o Hamutuk Timor-Leste Institute for Development Monitoring and Analysis, described this situation as 'oil swamping the entire economy of Timor-Leste' (2015a: 74). 


\section{Rent and political institutions}

One aspect of rentier state theory concerns the political institutions that rent generates and sustains. Scholars like Ross (2012a), Auty (2012) and Karl (1997) have identified different political institutions in petroleumdependent countries, examining how rent affects democratic institutions. Ross (2012a) has pointed out that dependency on externally derived revenues undermines democratisation. From a fiscal standpoint, as oil provides easy money, the state operates independent of the domestic economy and does not extract revenue from society through tax (Ross 2012a). This enables the state to be independent from societal structure (Schwarz 2008: 602). It is argued that this fiscal independency undermines public pressure on public officeholders to be accountable to their constituents (Ross 2012a). From the expenditure side, having access to oil enables politicians to coopt different social forces, thus undermining political pressure for democratic reforms (Owen 2004: 122; Ross 2012a). In the Middle East, although oil facilitates state expansion, it also increases the chances for family-type political regimes (Kamrava 2005; Owen 2004).

Patronage politics is another problem associated with rent dependency (Auty 2012; Karl 1997; Dunning 2008). Although this is not an issue unique to oil-dependent countries, the fact that petroleum revenues are concentrated on the executive branch of government makes it more pervasive. According to Karl (1997), oil creates conditions for the centralisation of power in the hands of the executive; the chief of the executive has the final decision over revenue allocation. This drives elites' competition to control rent (Auty 2012). In guaranteeing their survival, political elites make compromises in order to maintain the representation of the dominant class while limiting the scope of representation of the wider political spectrum (Karl 1997). Meanwhile, patron-client relationships, rent-seeking and the distribution of petrodollars become mechanisms to contain political resentment and ensure regime survival (Karl 1997).

In The Bottom Billion (2007), Paul Collier argues that rent generates patronage politics because voters are bribed with public money. Similarly, examining rentier state dynamics in East Asia and the Pacific, Barma states that political authority is individualised, 'resting on ... cronyism', 'public resources are ... exploited for private gain', and rent distribution 
is 'dominated by a concentrated elite' (Barma 2014: 260). Furthermore, '[p]olitical competition takes place ... on the basis of extended patronclient networks', and 'public goods are provided to ... mobilise (political) supporters' (ibid.). This clientelism can take various forms, including electoral politics and political parties. 'Political parties' in this context refers to the institutionalisation of clientelist politics, which facilitates the distribution of benefits among party members (Hopkin 2006). As the state expands its societal role in terms of regulations, financial benefits and public service provision, this network expands as well (ibid.). Voters exchange their votes for various benefits through state institutions (ibid.).

How is this relevant for Timor-Leste? Timor-Leste is generally regarded as a democratic country, despite some issues in upholding the rule of law and freedom of the press (Feijó 2015: 59). Freedom House (2016) categorised Timor-Leste as 'partly free', with a score of 65 out of 100 ( 0 being 'least free' and 100 being 'most free'). Its score for political and civil rights was 3 in a range from 1 to 7 ( 1 represents the 'most free' and 7 represents the 'least free'). Since 2007, Timor-Leste has also enjoyed political stability. In 2017, its third election was held since the restoration of independence; this was viewed as a free and fair election.

However, the country faces the challenge of growing patron-client relations that are increasingly shaping the political system. This issue has been discussed by scholars such as Rui Feijó (2015), James Scambary (2015) and Naazneen H. Barma (2014), and acknowledged by the former commissioner of Timor-Leste's Anti-Corruption Commission, Aderito de Jesus Soares (2015). Critically examining resource income expenditure in Timor-Leste, James Scambary (2015: 285) argues that 'the convergence of a range of historical, political and cultural factors, and resource wealth has laid the foundations for a clientelist and neo-patrimonial state'. One aspect of clientelism, according to Barma (2014: 266), is that most of the spending goes towards 'enriching the elite'. Both terms - clientelism and patrimonialism - refer to 'politically targeted modes of distribution of state funds' (Scambary 2015: 287). The former entails the distribution of favours or goods between individuals with unequal economic and social status, a relationship that might be mediated by 'brokers' (ibid.). 'The term neo-patrimonialism denotes a lack of distinction between office and office holder masked behind discourses, juridical norms, and institutions that nourish the illusion of a legal-bureaucratic logic' (ibid.: 288). 
Led by Dr Rui Maria de Araújo, the Sixth Constitutional Government in 2015 was seen as a new phase in Timor-Leste's political process. Official narratives presented the current government plans as 'TimorLeste's model' to strengthen democracy, peace and stability based on national consensus - it is not coincidental that the sixth government of Timor-Leste describes itself as a 'Government of National Unity'. However, the opposing argument holds that this national consensus is a mechanism to serve elites - rather than national - interests, as indicated by the Centre of Studies for Peace and Development (CEPAD 2015: 42). Such observations are pertinent considering Timor-Leste's political developments since 2012. The vast, ambitious ZEESM (Zonas Especiais de Economia Social de Mercado de Timor-Leste, or Special Economic Zone of Social Market Economy of Timor-Leste) project in Oecusse is the direct result of elites' consensus to distribute the oil money. ${ }^{1}$ An ad hoc committee (Komisaun Eventual) was established in December 2015 to discuss the annual state budget behind closed doors, which has aroused suspicion that it is a strategy to protect the interests of the elites (La'o Hamutuk 2015). In February 2016, then president Taur Matan Ruak expressed many of these concerns in a speech to parliament: 'Do not count on the president of the republic to build a society based on power and privileges' (Ruak 2016).

Like Scambary, Barma (2014: 263) argues that clientelism is an emerging trend in Timor-Leste and is recognised among some observers in Timor. The trend manifests itself in the ability of political parties to distribute public resources (ibid.: 266) and in the increasing concentration of power in the hands of the executive (ibid.: 263). Rui Feijo outlined two alternatives to the challenge of how Timor-Leste might manage its wealth: either following 'clearly defined procedures, institutionally framed, and validated through the rule of law', or one that involves 'ad hoc policies, and individual negotiations between the state and private agents, privileging personal ties over individual norms' (Feijó 2015: 64). If such a course of action became a dominant trend, according to Feijó (ibid.), it could 'generate dependency on social and economic actors' with regards to powerholders; furthermore, it could strengthen clientelist networks. A case used as the basis for this claim is the verification process to become officially considered a veteran, which is 'rumoured to be prone to abuses

1 According to Laura Meitzner Yoder (2015: 300), the public project is 'a fantastical development scheme for the geographically and politically peripheral' Oecusse district. 
and manipulation' owing to the lack of 'a clearly defined set of upheld legal procedures' (ibid.). The allegation of political patronage seems to have played a role in the contract distribution for the 2009 Pakote Referendum (Referendum Package), the government's US\$70 million investment in (mainly rural) infrastructure projects (Barma 2014: 265; Feijó 2015: 65).

Soares has reinforced Feijós critical observation with regards to the way the government has contracted the private sector for infrastructure development, observing that the fetishising of the private sector in development can result in favouritism towards certain businesses, bypassing laws and procedures, and lead to corruption' (Soares 2015: 210). One example of this practice is the government's decision to award infrastructure projects to Consorcio Nacional Timorense (Timorese National Consortium), made up of a 'small group of national contractors' through a 'single source mechanism' (Barma 2014: 265; Soares 2015: 210). This is only one of many instances where the government used a single source process to award contracts to individual businesses, which then 'created the perception of corruption' (Soares 2015: 210). Meanwhile, the practice of brokering foreign contractors' access to 'the state's recent multimilliondollar project tenders' also creates patron-client relationships in the Timorese economy (ibid.: 210-211).

These growing clientelist networks, I would argue, put the democratic process under threat, as democratic institutions are increasingly rendered to protect patron-client relationships. This is a threat to overall development in Timor-Leste, as it favours certain individuals who are part of clientelistic networks and undermines efforts for collective good (Hopkin 2006). Furthermore, these networks are unjust and inefficient, since the people who are part of them receive a disproportionate amount of benefits compared to the rest of Timor-Leste's citizens (ibid.). Additionally, sustaining political institutions through rent is an inefficient and unhealthy action for economic development; since it is based on elites' ability to control (and hence benefit from) oil rents, it leads to unpredictability for the private sector. These challenges to the country's peace will inevitably arise once the financial benefits from oil have been depleted. If efforts to reform pose a threat to the vested interests of dominant political actors, the growing clientelistic network will inevitably inhibit any such movements. 


\section{Bureaucratic expansion and efficiency}

The expansion of bureaucracy is an important part of the current development process. Since 2008, state bureaucracy has expanded rapidly, a process that has been facilitated by oil revenue. In 2015, TimorLeste's state spending on wages and salaries was US\$177.5 million, or 11.6 per cent of the total annual budget, and its expenditure on goods and services was US\$515.8 million, or 32.8 per cent of total annual spending (MoF 2015: 13). The expansion of state bureaucracy in TimorLeste follows the pattern of other oil-dependent countries; according to Nazib Ayubi (1990: 131), this is a common consequence of oil wealth. As revenue goes directly into the state's coffers, bureaucratic expansion is part of the state's distributive and allocative roles in society (Ayubi 1990: 136). Michael Ross writes that the government structure of rentier states was, on average, 45 per cent larger than those of their neighbours without oil (Ross 2012b: 28). The peak of Timor-Leste's expansion in state bureaucracy took place between 2012 and 2014, when there were 55 government ministers, vice-ministers and secretaries of state in a country with just 1.1 million people: '[I]t was the largest government in the Asia Pacific' (Horta 2014).

Patron-client relations are part and parcel of Timor-Leste's public institutions, which is a typical symptom of clientelism. This manifests in recruitment and promotion according to political party loyalties in an increasingly politicised public administration. This can be seen in popular expressions about the need to have 'someone inside' (ema laran), a 'godfather' or 'guardian' (Aman Sarani), or 'one of our own' (ema ita nian). The Timorese capital is rife with allegations and rumours that the promotion process is based on political alignment and family affiliation, which tends to undermine creativity and innovation in the public sector. It also undermines meritocracy, as political or family connections are a shortcut to recruitment and promotion for higher positions.

Easy money from oil also enables the state to establish a variety of different institutions tasked with tackling the very same problems. However, rather than solving these problems, having different institutions with similar mandates leads to overlapping roles. Soares has coined the term 'institutional ritualism' to characterise this trend, in which policymakers view the creation of institutions as the solution instead of focusing on the problems themselves (Soares 2013: 93). The case he discusses concerns 
corruption, which is addressed by the ombudsman, the public prosecutor, the audit court, the Criminal Investigation Police and the AntiCorruption Commission (ibid.: 91-94). Another example of doubling up on roles concerns the oversight of the state's numerous construction projects, which involve the Ministry of Public Works and the National Development Agency. This has even created conflict between the two institutions regarding which is responsible for ensuring quality control in construction projects. Moreover, when the state spends a large amount of money in a context where administrative capacity is weak, it leads to inefficient spending and misuse of public resources.

Allegations and perceptions of corruption are on the rise, which I have observed in public discussions that I have attended, in newspapers, on television and from private conversations I have had with colleagues and friends. Such perceptions can also be observed through common expressions referred to in Soares' analysis of corruption: 'Kasih-uang habis perkara', an expression left over from the Indonesian occupation, which means 'The matter is finished once you have given the money'; the Tetum expressions 'Keta haluha ami nian serveiza' ('Don't forget our beer'); 'Nia ita nian ema rasik sa' ('He [or she] is one of our own people'); and 'buihois' and 'mau-hois' (terms for a corrupt female and corrupt male public officer, respectively) (Soares 2013: 88). Another reference to the ways in which one requires a guardian or patron to get employment is the notion of the 'big brother' (maun bo'ot), which has lead Soares to conclude that there is a 'Maun Bo'ot culture' in Timor-Leste. A maun bo'ot is a senior person who 'has strong leverage because of past experience as a former resistance leader or a former clandestine leader' (ibid.: 89) and therefore manages to act as a 'broker' to mediate exchanges between the 'big people' and the 'little man' (see also Scambary 2015: 287).

As the rentier state literature discussed earlier has highlighted, the bureaucracy and policies of a rentier state are affected by oil revenue because the state itself is responsible for allocating these revenues and distributing them to the rest of society. The availability of large quantities of money through oil rents incentivises politicians to spend this money quickly through public employment schemes, subsidies, labour market regulations and short-term and emergency projects. Petroleum money can lead to 'bureaucratic overstretch', which occurs when a government's revenues expand more quickly than its capacity to efficiently manage them (Ross 2012a: 3), leading to misuse of public resources. In the influential book The Paradox of Plenty, Karl (1997: 57) argued that oil 
revenues diminish the state's authority by causing 'rentier psychology, which disproportionately admires and rewards those who can "milk the cow" without effort rather than those engaged in less remunerative but more productive activities'.

\section{The economy and society}

From the perspective of common economic sense, one could expect that revenues extracted from natural resources like petroleum could be used to finance the investment necessary for the development of a country. However, since the late 1990s, scholars have found that instead of promoting economic growth, dependence on natural resources inhibits economic growth (Ross 2012a; Auty 2012).

If economic growth per se is an indicator of successful economic development, Timor-Leste should be considered exemplary. Over the last 10 years, the country's non-oil gross domestic product (GDP) has been growing, facilitated nevertheless by petroleum money. Non-oil-related growth has led to general improvement in quality of life, as observed in Timor-Leste's declining poverty rate based on the consumption-based measurement (NSD 2017). According to the report published by the National Statistics Directorate (NSD 2017), the percentage of those living in poverty decreased from 50.4 to 41.8 per cent between 2007 and 2014 (ibid.). Other improvements include the Human Development Index, which has increased by 27 per cent from 0.468 in 2000 to 0.595 in 2015 (OECD 2017: 11). Other notable improvements can be seen in amount of schooling, means of schooling and life expectancy (ibid.).

Nonetheless, it is more important to look at the structure of this growth and how it affects people's daily lives. There is a consensus among policymakers and observers that economic growth is primarily driven by public expenditure, which recycles the rent through state spending (ADB 2015; Inder and Cornwell 2016). For example, construction and public administration, which are the drivers of economic growth, are both directly linked to petroleum money, circulated through annual state spending, and located primarily in Dili (Scheiner 2014: 8). The trend of private sector investment remains flat; it, too, tends to concentrate in Dili and is directly linked to government spending (ADB 2015: 3). On the 
other hand, agriculture - the source of livelihood for approximately 70 per cent of the population - has declined (ADB 2015; Inder and Cornwell 2016).

Furthermore, the rent-based economic structure has created a distinct middle class that is concentrated in urban areas, primarily Dili. For the most part, they are the main beneficiaries of recycled oil rent. This has widened the gap between those in Dili and the rest of the country. Although the national poverty line decreased between 2007 and 2014, the rural poverty rate is 19.8 per cent higher than its urban counterpart (NSD 2017: 6). Dili stands to be an outlier, with a poverty rate of 29.1 per cent, while the national poverty rate is 41 per cent (NSD 2016: 25). As various studies have pointed out, private sector activities in Timor-Leste also tend to be centralised in Dili (ADB 2015). In 2016 alone, it was estimated that almost 80 per cent of employment in the private sector was concentrated in Dili (NSD 2017: 3). Differences in quality of life are also reflected in the 2016 Public Perception Survey, conducted by The Asia Foundation (2017). The survey revealed that respondents in Dili were more satisfied in terms of public services such as health, education, water and sanitation (The Asia Foundation 2017: 6). Some observers were already issuing warnings in 2011 about the path of development that the country was taking. In the report of her visit to Timor-Leste in November 2011, Magdalena Sepúlveda Carmona, the United Nations Special Rapporteur on extreme poverty and human rights highlighted that despite 'rapid economic growth', 'most Timorese continue to experience poverty, deprivation and insecure employment' (Carmona 2012: 4).

Although a rent-based economy can grow, not much new employment will be generated. Most of the employment in the formal sector is concentrated in the public sector and the nation's capital. According to the 2013 Labour Force Survey, out of a working-age population of 696,200, the labour force participation rate was only 30.6 per cent (NSD 2013: 5). In the same survey, 483,000 were categorised as 'inactive population', out of which 37 per cent were involved in subsistence foodstuff production (ibid.). In 2010, the total amount of those employed in the private sector was 46,700 (NSD 2012: 3); in 2016, this number was estimated to be 58,200 (NSD 2017: 3). This shows that a limited amount of jobs were created in the formal sector during the period when the government's spending was high, but the domestic economy - measured by the non-oil GDP - grew significantly. 
As more people enter the job market, the limited employment opportunities generated by the economy have put pressure on the government to respond to such high demand for jobs. The challenge, as recognised by the government (GoTL 2017a: 7), is how to generate employment given that a high proportion of those of productive age live outside of the formal sector, yet 200,000 people will reach working age in the next 10 years (ibid.). Additionally, limited and concentrated employment opportunities drive another social problem: high internal migration to urban areas, primarily Dili. Between 2004 and 2015, the proportion of Timor-Leste's urban population grew from 25 per cent to 33 per cent (Nguyen et al. 2017: 4). During the same period, the population grew from 158,000 to 255,000 in Dili alone - an increase of 62 per cent (ibid.). The evidence suggests that the difference in quality of life is the major factor in this influx of urban migration (ibid.).

Realising the challenges that the country is - and will be - facing, particularly in a context of declining petroleum revenue, 'economic diversification' has become a common expression in policy debate and discussion in Dili (Inder and Cornwell 2016: 6). The previous government, led by Rui Maria Araujo, has provided guidance for 'reform and economic growth' (GoTL 2017b: 134). Alongside the oil sector, the government also prioritises the agriculture, tourism, fisheries and manufacturing industries as the potential sectors for Timor-Leste's development. The government's approach focused on the 'enabling environment' by investing in infrastructure such as electricity and roads, revising legal frameworks such as land, property and private investment law, taking part in the One-Stop Shop SERVE trade investment, and other interventions (GoTL 2017b).

While these are issues faced by people on the technical level, one cannot neglect the political and institutional issues - namely, the economic institutions sustained by the rent and the incentives that exist for them. Economically, rent is the result of earning high profits from economic activities that require a disproportionately low level of productivity (Kamrava 2005: 267). Petroleum revenue is rent because 'the economic return to natural extraction ... exceeds production and transport costs and some "normal" return to capital', even when all the production factors are at their optimum capacity (Dunning 2008: 39). This is made more difficult by the fact that petroleum is non-renewable, volatile, capital-intensive and high-technology (Karl 2007: 3; Ross 2012a). When a country depends excessively on its petroleum revenues, it creates a rentier economy in which rent can 'sustain the economy without a strong domestic 
productive sector' (Beblawi 1987: 385). This shapes the mentality of the elites who control the state in various ways; there is a tendency for elites to ignore the developing non-oil economy, since the state's income is not derived from the domestic economy (Luciani 1987: 69).

This trend can be observed in the overall development path that TimorLeste is taking, as well as its budget allocation (Scheiner 2015a). Access to rent diverts decision-makers' attention from investment in sectors that are more sustainable (ibid.). Rent makes it easier to buy education and healthcare services from outside the country than to invest locally; easier to import rice than to plant it; and easier to import technical advisers than to build domestic institutions (ibid.). Although government officials frequently state that agriculture is a development priority, this sector receives only 2 per cent of the state's annual budget. There is a strong perception that the younger generations do not want to be involved in agriculture anymore and that people are 'spoiled' by different state subsidies. This attitude was frequently expressed by people during my visits to Laleia, Suai, Balibo and other parts of the country.

The effect of rent dependency has also been transferred to the structure of society. Some groups do not participate in economic production, but share a big portion of the economic gain (Beblawi 1987: 49). In this economic structure, only a few people are involved in rent generation, whereas the majority play a role in either wealth 'distribution or utilisation' (ibid.). The state 'ends up by performing the role of allocating' the externally gained revenue throughout the economy (Luciani 1987: 69). Although most people's incomes increase 'in the short run', the rich and 'powerful benefit disproportionately' from oil revenue, which deepens social inequality (Karl 1997: 65, citing Lewis 1982). Most citizens want a piece of 'oil pie' without having to work hard (ibid.). Citizens growing up in these conditions are accustomed to these subsidies, expecting them to continue without recognising that oil will be depleted (ibid.).

Coined by The Economist, the term 'Dutch disease' refers to a situation in which the boom in the natural resources sector produces a decline in the manufacturing and agriculture sectors (Ross 2012a: 21; see also the Introduction to this volume). When a resource boom occurs, it takes away labour and capital from the agriculture and manufacturing sectors, which raises the cost of production. Additionally, when revenues from these resources enter the market, the real exchange rate increases. This makes it cheaper to import agricultural and manufactured goods than to produce 
them locally. The price will remain the same for the products that are imported, given that it is determined by the international market. Therefore, both sectors lose their share of the domestic market (ibid.). Signs of this phenomenon can be observed in Timor-Leste. My engagement with the local communities in Maliana, Balibo, Suai and Laleia has shown that a high level of subsidies disincentivises local communities from engaging in productive sectors.

Timor-Leste faces an even larger challenge, however. It lacks the basic infrastructure to assist in the emergence of a modern private sector, and the public sector's institutional capacity to support one is weak. Numerous existing policies tend to undermine the government's efforts to strengthen the private sector, including those related to rice import, the high proportion of cash transfer programs, and a low allocation of budget funds for productive sectors. As observed by Beblawi (1987: 385), domestic production suffers from high levels of importation, combined with a rentier mentality, which 'embodies a break in the work-reward' relationship.

\section{Envisioning Timor-Leste's future}

When Rui Araújo came to power in 2015, he promised to bring efficiency to the government. He then launched several reform agendas - namely, Civil Service Reform, Economic Reform, Legal Reform and Fiscal Reform. It was argued that these reforms were part of Timor-Leste's efforts to carry out its strategic development plan and meet sustainable development goals. My observation is that these reforms address some of the technical issues that are faced in modern-day Timor-Leste. However, they do not address the political economic aspects of development, which are influenced by petroleum rent and the reality of Timor-Leste as a post-conflict society.

While the country's strategic development plan provides a vision of modernity based on oil, this chapter lays out some of the present and future challenges posed by the centrality of oil in Timor-Leste's economy. First is the challenge for the democratic system, which is visible in the way patron-client relations have begun to shape democratic institutions. If this trend continues, the political system will become more oriented towards the protection of the elites' interests, while the majority of people will be excluded from the political process. Elections can still be a democratic 
means for people to participate, but they can also be a mechanism for the elites to expand their client networks and legitimise their position through the electoral framework. If patron-client relations come to penetrate institutions more pervasively, it will erode the legitimacy of democratic institutions.

The second issue concerns sustainable and equitable development. The discussion on sustainable development in Timor-Leste seems to have a narrow focus on financial aspects. This is due to public anxiety regarding oil prices, as well as declining oil reserves. The discussion then leads us to another question: How long will petroleum sustain Timor-Leste's development? However, as this chapter has outlined, there are many other compelling reasons to rethink sustainability and development in Timor-Leste beyond oil. Oil-based development is unsustainable not only because oil is running out, but because the development outcomes that oil rent promotes are highly problematic and socially harmful. Oil dependency creates social, political and economic structures that exclude the majority of people from the development process and empowers the urban elites who control the state. It benefits the capital city over rural areas where the majority of people live. A vision of the future of TimorLeste based on oil is a vision that will decidedly benefit the elites. If we are to envision a future that includes and benefits everyone, it will have to be one without oil.

\section{References}

ADB (Asian Development Bank) (2015) Growing the non-oil economy: A private sector assessment for Timor-Leste. Available at: www.adb.org/sites/default/files/ institutional-document/161516/tim-growing-non-oil-economy.pdf.

Auty, M. A. (2012) 'Introduction and overview', in Auty, R. M. (ed.) Resource abundance and economic development, Oxford: Oxford University Press, pp. 3-16.

Ayubi, N. (1990) 'Arab bureaucracies: Expanding size, changing roles', in Luciani, G. (ed.) The Arab state, Berkeley: University of California Press, pp. 129-149.

Barma, N. H. (2014) 'The rentier state at work: Comparative experiences of the resource curse in East Asia and the Pacific', Asia and the Pacific Policy Studies vol. 1, no. 2, pp. 257-272. doi.org/10.1002/app5.26. 
Beblawi, H. (1987) 'The rentier state in the Arab world', Arab Studies Quarterly, vol. 9, no. 4, pp. 383-398.

Carmona, M. S. (2012) Annex: Report of the Special Rapporteur on extreme poverty and human rights on her mission to Timor-Leste (13-18 November 2011), Report A/HRC/20/25/Add.1, General Assembly, Human Rights Council, 20th Session. Available at: www.ohchr.org/Documents/HRBodies/ HRCouncil/RegularSession/Session20/A.HRC.20.25.Add.1_En.PDF.

CEPAD (Centre for Study, Peace and Development) (2015) Rezilensia husi Perspektiva Lokal: Mekanismu atu Kompriende Reziliensia. Timor-Leste Relatoriu Nasional [Resilience from a local perspective. Mechanisms for understanding resilience. Timor-Leste National Report], Dili: CEPAD/ Interpeace. Available at: www.interpeace.org/wp-content/uploads/2015/05/ 2015_05_19_FAR_Relatoriu_Nasional_TET.pdf.

Collier, P. (2007) The bottom billion: Why the poorest countries are failing and what can be done about it, Oxford: Oxford University Press.

Coronil, F. (1997) The magical state: Nature, money, and modernity in Venezuela, Chicago: University of Chicago Press.

Dunning, T. (2008) Crude democracy: Natural resource wealth and political regimes, New York: Cambridge University Press. doi.org/10.1017/CBO 9780511510052 .

Feijó, R. G. (2015) 'Challenges to the consolidation of democracy', in Ingram, S., Kent, L., and McWilliam, A. (eds) A new era? Timor-Leste after the UN, Canberra: ANU Press, pp. 59-70. doi.org/10.22459/NE.09.2015.05.

Freedom House (2016) Timor-Leste: Freedom in the world 2016. Available at: freedomhouse.org/report/freedom-world/2016/timor-leste.

GoTL (Government of Timor-Leste) (2011) Timor-Leste strategic development plan 2011-2030. Available at: sustainabledevelopment.un.org/content/ documents/1506Timor-Leste-Strategic-Plan-2011-20301.pdf.

GoTL (2017a) National employment strategy 2017-2030: Productive employment shall be a central means of national building and wealth creation. Available at: timor-leste.gov.tl/wp-content/uploads/2017/07/National-EmploymentStrategy-2017-20301.pdf.

GoTL (2017b) Snapshot of sixth constitutional government mandate (2015-2017). Available at: timor-leste.gov.tl/wp-content/uploads/2017/08/Low_EN_Texto _VI-GOVERNO-CONSTITUCIONAL1.pdf. 
Hopkin, J. (2006) 'Clientelism and party politics', in Katz, R. S. and Crotty, W. (eds) Handbook of party politics, London: SAGE Publications Ltd, pp. 406412. doi.org/10.4135/9781848608047.n35.

Horta, L. (2014) 'Timor-Leste: Lessons from a failing state?' Yale Global Online, 22 May. Available at: yaleglobal.yale.edu/content/timor-leste-lessons-failingstate.

Inder, B. and Cornwell, K. (2016) Private sector-driven development in an infant economy. Monash Centre for Development Economics and Sustainability Research, Research Paper Series on Timor-Leste. RP-TL4-English. Available at: www.laohamutuk.org/econ/invest/RP-TL4-English.pdf.

Kamrava, M. (2005) The modern Middle East: A political history since the First World War, Oakland: University of California Press.

Karl, T. L. (1997) The paradox of plenty: Oil booms and petro-states, Oakland: University of California Press.

Karl, T. L. (2007) Oil-led development: Social, political, and economic consequences, Working Paper No. 80, Stanford: Center on Democracy, Development and the Rule of Law, Stanford University.

La'o Hamutuk (2011) Submission to Committee C: Economy, finances and anticorruption, National Parliament, Democratic Republic of Timor-Leste: regarding the proposed General State Budget for 2012, La'o Hamutuk - The TimorLeste Institute for Development Monitoring and Analysis. Available at: laohamutuk.org/econ/OGE12/LHSubComCPNOJE2012En.pdf.

La'o Hamutuk (2015) Submission to Timor-Leste National Parliament on the proposed General State Budget for 2016, La'o Hamutuk - The Timor-Leste Institute for Development Monitoring and Analysis. Available at: www.laoha mutuk.org/econ/OGE16/LHSubPNOGE16-18Nov2015en.pdf.

Lewis, S. R. (1982) Development problems of the mineral-rich countries, Center for Development Economics, Research Memo 74, Williamstown: Williams College.

Luciani, G. (1987) 'Allocation vs. production states: A theoretical framework', in Beblawi, H. and Luciani, G. (eds) The rentier state (Nation, state and integration in the Arab world, vol. 2), London: Croom Helm, pp. 63-82.

Mahdavy, H. (1970) 'The patterns and problems of economic development in rentier states: the case of Iran', in Cook, M. A. (ed.) Studies in the economic history of the Middle East: From the rise of Islam to the present day, London: Oxford University Press, pp. 428-467. 
Meitzner Yoder, L. S. (2015) 'The development eraser: Fantastical schemes, aspirational distractions and high modern mega-events in the Oecusse enclave, Timor-Leste', Journal of Political Ecology, vol. 22, pp. 299-321. doi.org/10.2458/v22i1.21110.

MoF (Ministry of Finance [GoTL]) (2015) State Budget 2015: Budget Overview. Available at: laohamutuk.org/econ/OGE15/bksOct14/OGE15Bk 1Oct2014en.pdf.

Neves, G. (2011) 'Timor's oil: Blessing or curse?', Foreign Policy in Focus, 26 August. Available at: fpif.org/timors_oil_blessing_or_curse/.

Neves, G. (2013) 'Timor-Leste: The political economy of a rentier state', in Loney, H., Da Silva, A. B., Da Costa Ximenes, A., Canas Mendes, N. and Fernandes, C. (eds) Understanding Timor-Leste, vol. 2, 4th Timor Leste Studies Association Conference, 15-16 July, Dili, Hawthorn: Swinburne Press, pp. 22-26.

Neves, G. (2016) The political economy of petroleum dependency, SSGM In Brief 2016/6, Canberra: State, Society \& Governance in Melanesia, ANU. Available at: ssgm.bellschool.anu.edu.au/experts-publications/publications/ 3630/political-economy-petroleum-dependency.

Nguyen, P., Cornwall, K., Inder, B., and Qu, N. (2017) An economic perspective on people movement in Timor-Leste, Centre for Development Economics and Sustainability, Monash University. Available at: drive.google.com/file/ d/0ByznZLkW5XMKSFpwMEdEcjFrRmM/edit.

NSD (National Statistics Directorate [GoTL]) (2012) Business activity survey of Timor-Leste 2010. Available at: www.statistics.gov.tl/wp-content/uploads/ 2013/12/BAS_202010_20ENGLISH.pdf.

NSD (2013) Labor force survey 2013. Available at: www.ilo.org/wcmsp5/ groups/public/---asia/---ro-bangkok/---ilo-jakarta/documents/publication/ wcms_417168.pdf.

NSD (2015) Timor-Leste national accounts 2000-2014. Available at: www. statistics.gov.tl/wp-content/uploads/2016/06/TL-NA-2000-2014.pdf.

NSD (2016) Business activity survey of Timor-Leste 2014. Available at: www.statistics. gov.tl/wp-content/uploads/2016/06/Bussines-Activity-Survey-2014-.pdf.

NSD (2017) Poverty in Timor-Leste 2014. Available at: www.statistics.gov.tl/wpcontent/uploads/2018/02/Poverty-Report-2014-final.pdf. 
OECD (Organisation for Economic Co-operation and Development) (2017) Budgeting for a sustainable future: Towards a roadmap of budgetary governance reform in Timor-Leste (presentation). Available at: www.slideshare.net/OECDGOV/budgetary-governance-reforms-in-timorleste-ronnie-downes-oecd.

Owen, R. (2004) State, power and politics in the making of the modern Middle East, 3rd edition, New York: Routledge.

Ross, M. L. (2012a) The oil curse: How petroleum wealth shapes the development of nations, Princeton: Princeton University Press.

Ross, M. L. (2012b) The political economy of petroleum wealth in low-income countries: Some policy alternatives, Economic Research Forum Working Paper No. 708, Giza, Egypt: Economic Research Forum. Available at: erf.org.eg/ wp-content/uploads/2014/08/708.pdf.

Ruak, T. M. (2016) 'Speech by His Excellency the President of the Republic, Taur Matan Ruak, to the National Parliament', Life at Aitarak Laran, 26 February. Available at: aitaraklaranlive.wordpress.com/2016/02/26/speechby-his-excellency-the-president-of-the-republic-taur-matan-ruak-to-nationalparliament-on-the-dismissal-of-major-general-lere-anan-timur/.

Scambary, J. (2015) 'In search of white elephants: The political economy of resource income expenditure in East Timor', Critical Asian Studies, vol. 47, no. 2, pp. 283-308. doi.org/10.1080/14672715.2015.1041281.

Scheiner, C. (2014) How long will the Petroleum Fund carry Timor-Leste? La'o Hamutuk - The Timor-Leste Institute for Development Monitoring and Analysis. Available at: www.laohamutuk.org/econ/model/ScheinerPetrolFund 17Feb2014en.pdf.

Scheiner, C. (2015a) Can the Petroleum Fund exorcise the resource curse from Timor-Leste? La'o Hamutuk - The Timor-Leste Institute for Development Monitoring and Analysis. Available at: www.laohamutuk.org/econ/exor/ ScheinerFundExorciseCurseJun2015en.pdf.

Scheiner, C. (2015b) 'Fiscal strategies and their implications for wealth distribution', Paper presented at ANU Timor-Leste Update Conference, 19-20 November 2015, Canberra. Available at: www.laohamutuk.org/econ/ briefing/ScheinerANUNov2015.pdf.

Schwarz, R. (2008) 'The political economy of state-formation in the Arab Middle East: Rentier states, economic reform, and democratization', Review of International Political Economy, vol. 15, no. 4, pp. 599-621. doi.org/10.1080/ 09692290802260662. 
Soares, A. de J. (2013) 'Combating corruption: Avoiding "institutional ritualism"', in Leach, M. and Kingsbury, D. (eds) The politics of Timor-Leste: Democratic consolidation after intervention, New York: Cornell University Press, pp. 85-97.

Soares, A. de J. (2015) 'A social movement as an antidote to corruption', in Ingram, S., Kent, L. and Andrew McWilliam, A. (eds) A new era? TimorLeste after the UN, Canberra: ANU Press, pp. 203-212. doi.org/10.22459/ NE.09.2015.13.

The Asia Foundation (2017) Timor-Leste 2016 Tatoli! Public opinion poll. Available at: asiafoundation.org/wp-content/uploads/2017/06/2016-TatoliSurvey-Report-ENGLISH.pdf.

World Bank (2013) Timor-Leste social assistance public expenditure and program performance report, Report No. 73488-TP, Social Protection and Labor Human Development Sector Unit, East Asia and Pacific Region. Available at: documents.worldbank.org/curated/en/193531468117251571/pdf/734840 WP0P126300PER000240June00eng.pdf.

World Bank and Ministry of Finance (GoTL) (2015) Democratic Republic of Timor-Leste public expenditure review: Infrastructure, Report No. AUS6142, GMFDR, East Pacific and Pacific. Available at: openknowledge. worldbank.org/bitstream/handle/10986/22367/PERI0FINAL00WB0site0. pdf;sequence $=1$. 
This text is taken from The Promise of Prosperity: Visions of the Future in Timor-Leste, edited by Judith Bovensiepen, published 2018 by ANU Press, The Australian National University, Canberra, Australia.

doi.org/10.22459/PP.2018.03 